\title{
The Tomb and Helm Of Thomas La Warre, In The Church at Broadwater, Sussex
}

\section{W. Burges}

To cite this article: W. Burges (1879) The Tomb and Helm Of Thomas La Warre, In The Church at Broadwater, Sussex, Archaeological Journal, 36:1, 78-87, DOI: 10.1080/00665983.1879.10851871

To link to this article: http://dx.doi.org/10.1080/00665983.1879.10851871

$$
\text { 册Published online: } 14 \text { Jul } 2014 .
$$

Submit your article to this journal $\sqsubset \pi$

Q View related articles $₫$

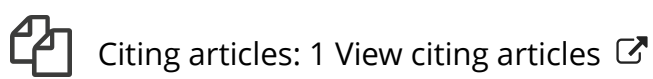




\title{
THE TOMB AŇD HELA OF THOMAS LA WARRE, IN THE CHURCH AT BROADVITER, SUSSEX.
}

\author{
By W. BURGES.
}

The helm represented in the accompanying woodcuts is now preserved in the chancel of the parish church of Broadwater, about a mile from Worthing. Recent restorations have so altered the interior of the chancel that it is perfectly impossible to point out the ancient position of this piece of armour; but we shall be, probably, not far wrong in supposing it to have been placed on a bracket, on one side of the tomb of Thomas West Lord La Warre, who flourished in the reigns of Henry VII. and Henry VIII.

It has now been restored to the position in question; but a few months ago it was lying on the top of the altartomb, within everybody's reach, the visor loose and the lower part of the back piece broken off and detached.

By the kind offices of a friend at Worthing, I was permitted by the churchwarden to take this helm to London, where it was exhibited at a Meeting of the Archrological Institute and afterwards carefully photographed.

Subsequently the hinges of the visor were made right, the detached part of the back rivetted on to the main piece, and the whole carefully cleaned and repainted. It is now placed on an iron bracket on the west side of the tomb, at a sufficient height to be out of reach except by means of a ladder.

But before proceeding to a description of the helm it may perhaps be as well to say a few words about its ancient possessor.

The first mention of the Wests dates as far back as Edw. II., when a Sir Thomas West narried the daughter and heiress of Sir Jolnn Cantelupe. Both he and his 
successors aggrandised the family by a series of fortunate marriages with the heiresses of the Cantelupes, Fitzherbert, La Warres, and St. Armands. At last in Henry VI.'s time the holder of the title was Richard La Warre, who, being a zealous Lancastrian, obtained from the king an annual pension of $£ 40$ to be levied out of the possessions of the Duke of York then attainted. But the wheel of fortune turned round. Edward IV. became king; and in the third year of his reign we find Richard getting license to go beyond the seas, and to take twelve servants and as many horses not exceeding the value of forty shillings a piece, and there to continue. $\mathrm{He}$ died in 16 th of Edw. IV., and Thomas, his son and heir, nineteen years old, obtained a special livery of his lands, although under age.

After the battle of Bosworth, 1485, it was the turn of the Lancastrians to be rewarded for their former sufferings, and we consequently find Thomas La Warre receiving certain possessions in Sussex which had been the property of the first Duke of Norfolk, slain in that battle.

In Dugdale's Baronage,' from which the foregoing details have been derived, will be found an epitome of the various public actions of this Thomas La Warre, who appears to have fulfilled all the duties of a great Baron of the period.

In 7 th Henry VII. he was one of the commanders sent into Flanders in aid of Maximillian, against the French.

In 12th Henry VII. he was in Cornwall with the forces raised to suppress the Cornish Insurrection.

2nd Henry VIII. he was made Knight of the Garter.

5th Henry VIII. he was in the army when Henry besieged Therouanne and Tournay.

6th Henry VIII. he attended Lady Mary to France, on her marriage with Louis XII.; he was in attendance, with other nobles, on the Emperor Charles $V$. from Gravelines to Calais and thence to Dover, when he paid his second visit to England.

17th Henry VIII. he made his will and died shortly after, in 1526.

1 Vol. ii, see [a Warre and West. 
By the will he bequeathed his body to be buried in a freestone tomb within the chancel of the parish church of Broadwater, appointing that his executors should bury him, according to his honor, and give twopence a piece to every poor man and woman who would come and receive it at the said church. Towards the charges thereof, he willed that his collar of gold of garters and chain that he usually wore should be sold. He likewise bequeathed to the said church of Broadwater, his mantle of blue velvet of the garter, and his gown of crimson velvet belonging thereto, to make two altar cloths.

He was twice married; first, to Elizabeth, daughter and heiress of Hugh Mortimer, and secondly, to Eleanor, daughter of Sir Roger Copley.

He died at Offington, close to Broadwater, 1526, aged 68.

Eleanor, his second wife, survived him some time, for, by her will, in 1536 , she desired to be buried in the same tomb as her husband.

He was succeeded by Thomas, his son by his first wife, who was also a Knight of the Garter. He married Elizabeth, heiress of Sir John Bonville, of Halnaker; and died in 1554 . He was buried at Broadwater, and the tomb, now at the east end of the south transept, doubtless belongs to him.

He was also the builder, probably at the death of his wife, of the charming renaissance chapel in the south side of the choir of Boxgrove Church. The inscription runs as follows:- "Of your charity pray for the souls of Thomas La Warre and Elizabeth his wife. Thomas La War anno dni 1532. Elizabeth la War."

Now these three monuments, viz. the two tombs in Broadwater Church and the Boxgrove chantry, are very curious as exhibiting the progress of the renaissance element and the extinction of the Gothic. Thus the chancel tomb at Broadwater is really a Gothic tomb with renaissance details; in the chantry at Boxgrove there is more of the renaissance style and less of the Gothic ; while in the Broadwater transept tomb, the whole is renaissance. Still from the details of the architecture and the ornaments--to say nothing of the costume of the figure of St. George yet remaining-it would certainly 
not be safe to attribute its erection to the time of his death in 1554.

It is more probable that this identical tomb was executed in his lifetime shortly after the erection in Boxgrove chantry. In fact all three monuments are possibly due to the same sculptor, and executed within ten years of each other. Prints of the chancel tombs and of the chantry are to be found in Dallaway's Sussex under the heads of Broadwater and Boxgrove.

The chancel tomb to the memory of the Thomas La Warre who died in 1525 follows a very common type of the period, an example of which, known to everybody, is afforded by the so called Chaucer tomb in Westminster Abbey.

The Broadwater monument occupies one of the northern bays of the vaulted channel. It may briefly be described as an elaborate canopy of three compartments, covering an altar tomb recessed in the wall.

Like many other monuments of this periorl, there was 110 eftigy; the altar tomb having a flat top, doubtless, for the purpose of being used as the Easter sepulchre. The sloping sides and back of the recesses in the wall are now plain, but from the description given in Dallaway's Sussex it is evident that they were occupied by paintings; and from plates of other tombs in his work, we can form a very fair idea of what these paintings represented.

In the centre of the back there still remains a sculptured coat of arms, quarterly West and La Warre enclosed in a garter, over it was, doubtless, a painted representation of the most Holy Trinity. On the dexter side was Lord La Warre kneeling; and on the sinister, his wife or wives. The patron saints (most probably St. George for the Lord) would occupy the sloping sides of the recess. The following is the account of the tomb by Cartwright, who published the completion of Dallaway's Sussex in 1830. "The whole was originally painted and gilt. The back of the tomb, with the sides which slant towards it, were painted with some legendary subjects, as was evident from the parts of figures which were discovered when the tomb was under repairs. The whole of the monument was obscured by a thick crust of whitewash when the late Hon. Mrs. Damer, whose skill in statuary is well 
known, and who was connected with the Delaware family, pitrtially restored it. It has since been repaired and cleaned by the direction of the present Earl Delaware."

The two tombs at the present day bear out the truth of the above account. In fact they have been very much restored, otherwise it would be difficult to explain the sharpness of the details three centuries after their execution in so friable a material as freestone.

The transept tomb has evidently. been moved from its original position, as it now lies north and south, like an altar, whereas the customary position for tombs was east and west. It is remarkable as containing figures of Our Lady and St. George, on either side of a centre group, representing the most Holy Trinity. This latter is much defaced, but the two others are in very good preservation.

As regards the helaldry of the chancel tomb, which more immediately concerns us:- -

In the centre of the back, and occupying the most prominent position, is a shield charged with another shield surrounded by the garter. This last shield bears quarterly La Warre (gules, a lion rampant, argent, armed and langued, az. between eight cross crosslets, fitche in orle of the second), and Cantelupe (azure, three leopards' heads jessant de lys, or.)

On the upper part of the octagonal buttresses are four shields in the following order, beginning from the west:-

1. Cantelupe, as above. 2. A shield, charged with T. \& E. (Thomas and Eleanor), connected by a knot. 3. T. \& L. (Thomas La Warre), similarly joined together. 4. a lion rampant, probably la Warre, with the cross crosslets omitted, probably in the restoration.

Lower down the side buttresses are two other shields-

1. A lion rampant, no cross crosslets. 2. Cantelupe.

The altar tomb contains four small shields charged with-1. A lion rampant. 2. A leopard's head, jessant de lys. 3. As 1. 4. As 2.

The buttresses are powdered with T's (Thomas), E's (Eleanor), the sword-shape badge of the La Warre's gained at Poitiers, and the leopard's head jessant de lys of the Cantelupes.

It will be seen that the family arms of neither of the wives appear. 


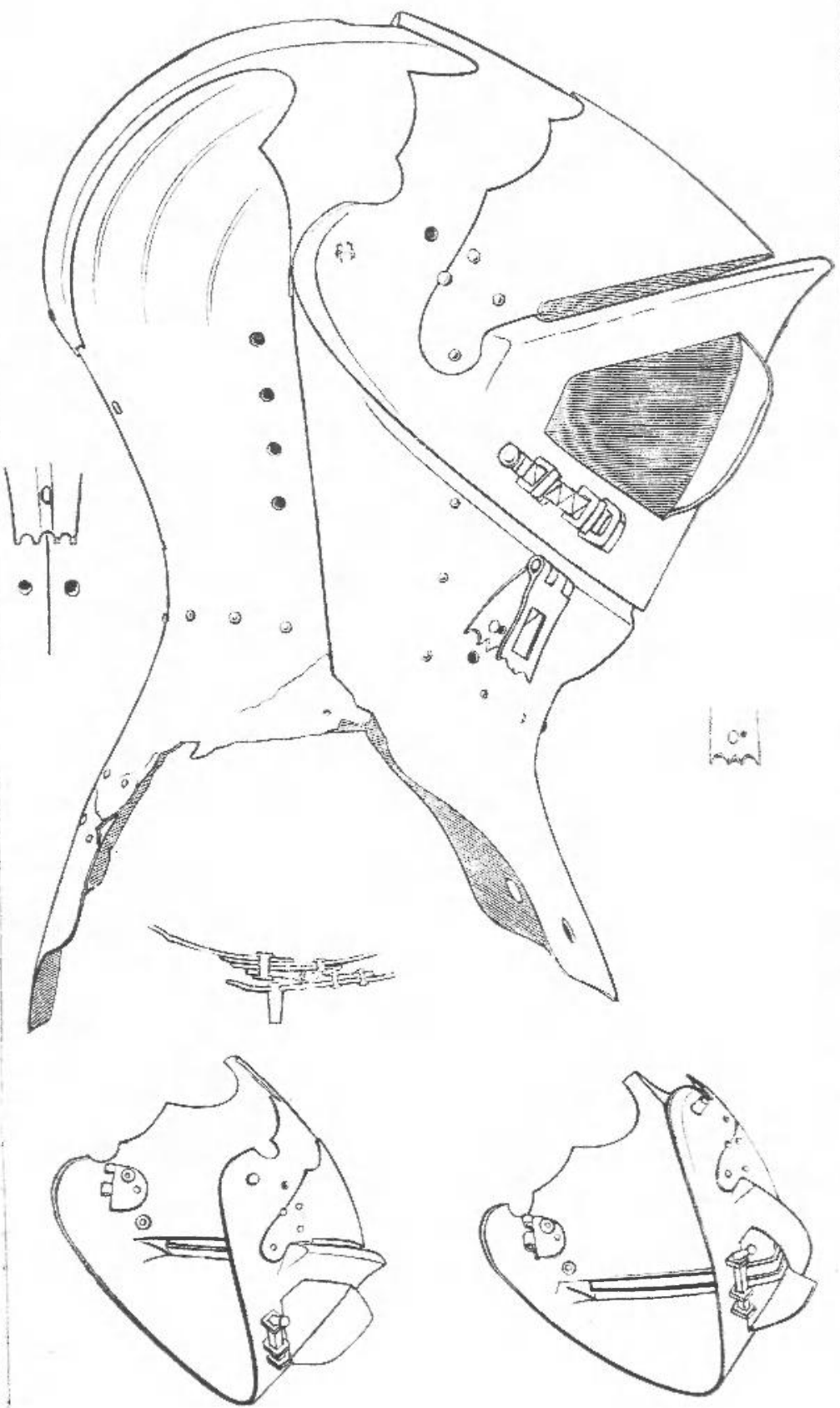


On the other hand, among the quarterings in the transept tomb, we find the arms of the mother Mortimer; viz :- barry of six or and azure, on a chief of the first, two pallets between two gyronnies of the second.

Before proceeding to consider the helm it may be as well to draw attention to a couple of heraldic anomalies in the chancel tomb. The first is the shield in the middle of the back of the recess, which is charged with another shield surrounded by the garter. The badges on shields in the side of the altar tomb form the second. The same arrangement occurs in the chantry at Boxgrove.

In the middle ages it was a very common custom to suspend portions of armour in the vicinity of tombs. In the case of the Black Prince we had two sets of arms, one for war and one for peace: of these there remain the helm, the gambeson. the gauntlets. the shield, a small sword sheath, and a belt. Over Henry V.'s tomb there is the tilting helmet, bought after his death (and consequently not used at Agincourt, as many writers are fond of asserting), the shield, and the saddle. ${ }^{1}$ There was the shield of John of Gaunt, figured by Dugdale in his old St. Paul's, but more frequently we find these arms represented by a helm or helmet only. These helmets or helms have now become very scarce, and it is much to be regretted that the Archæological Institute, or some other society, has not published a correct list of those now remaining in ecclesiastical custody.

Broadwater has, however, been fortunate in possessing a helm of a very uncommon type, and which there is every reason to believe belonged to the chancel tomb: its probable date, viz., the end of the reign of Henry VII., or the heginning of his successor, supports the popular tradition, and I think it may be assumed without much questioning; that it was an old helmet of Thomas Lord La Warre that

1 That the tilting helm over the chantry of Henry V at Westminster; could not have been worn at Agincourt is very evident from the facts-

1. That tilting helms would not be worn in actual warfare.

2. That S. Remi, in his Memoirs, tells us that the King "apres les messes dictes, fit apporter son harnois de teste, qui estait un tres bel bachinet a buriere."
3. The following extracts from Rymer, vol. 10 , p. $25 \%$, give us, in all probability, the history of the present tilting helm. 1422 , 1st Henry VI. Among the Particula provisa pro internamento Regis Henrici superdicti item eidem Thomse (Daunt) pro factura unius crestce et unius helnae pro Rege xxxiiis, ivd. 
was perhaps offered at his funeral or put up to adorn the tomb.

The helm consists of four principal and distinct parts : 1 , the back; 2 , the crown; 3 , the beaver ; 4 , the visor, the latter having a re-inforcing piece over the occularium

1. The back-piece is formed distinct from the crownpiece in order to avoid the difficulty of forging so large a piece as the two would have made if not divided; as it is, the crown-piece overlaps the back-piece by about an inch. On either side of the latter are three rudimentary ridges or flutings. A ridge goes down the back, but towards the bottom it is lost so as to allow the lower part to fit on easily to the back plate, to which it was attached by a staple which went through a hole five-eighths of an inch in diameter. At the lower part of the ridge are three holes, 2 and 1, most probably made for the purpose of affixing a plume holder or holders.

In the Tournament Roll, 1st Henry VII., now preserved in the Herald's College, the helms have no crests, but their place is supplied by feathers and scarves. The former appear to have been affixed to the top of the helmet, while the scarves were attached to the same place by means of a gilded ball.

The back-piece presents us with a row of rivets along the sides, doubtless, the attachments for the lining. They extend along the front edge of the crown-piece, whereas in the bottom of the back-piece the line they take runs along the middle of the neck; but there are no rivets for lining between this line and the bottom of the back-piece, althongh a small rivetted piece of iron on one side and traces of a similar one on the other, would seem to indicate that the lining was continued.

These little strips of iron are frequently found in the interior of helmets, and may have been the means of fastening down pieces of leather or canvass, to which the lining proper could have been sewn, for it must have been a very difficult affair to have lined such varying surfaces as one presented by the interior of a helm or helmet. On each side of the back piece are four small holes, placed one above the other, immediately over the position of the ears.

2. The crown-piece offers nothing very remarkable, 

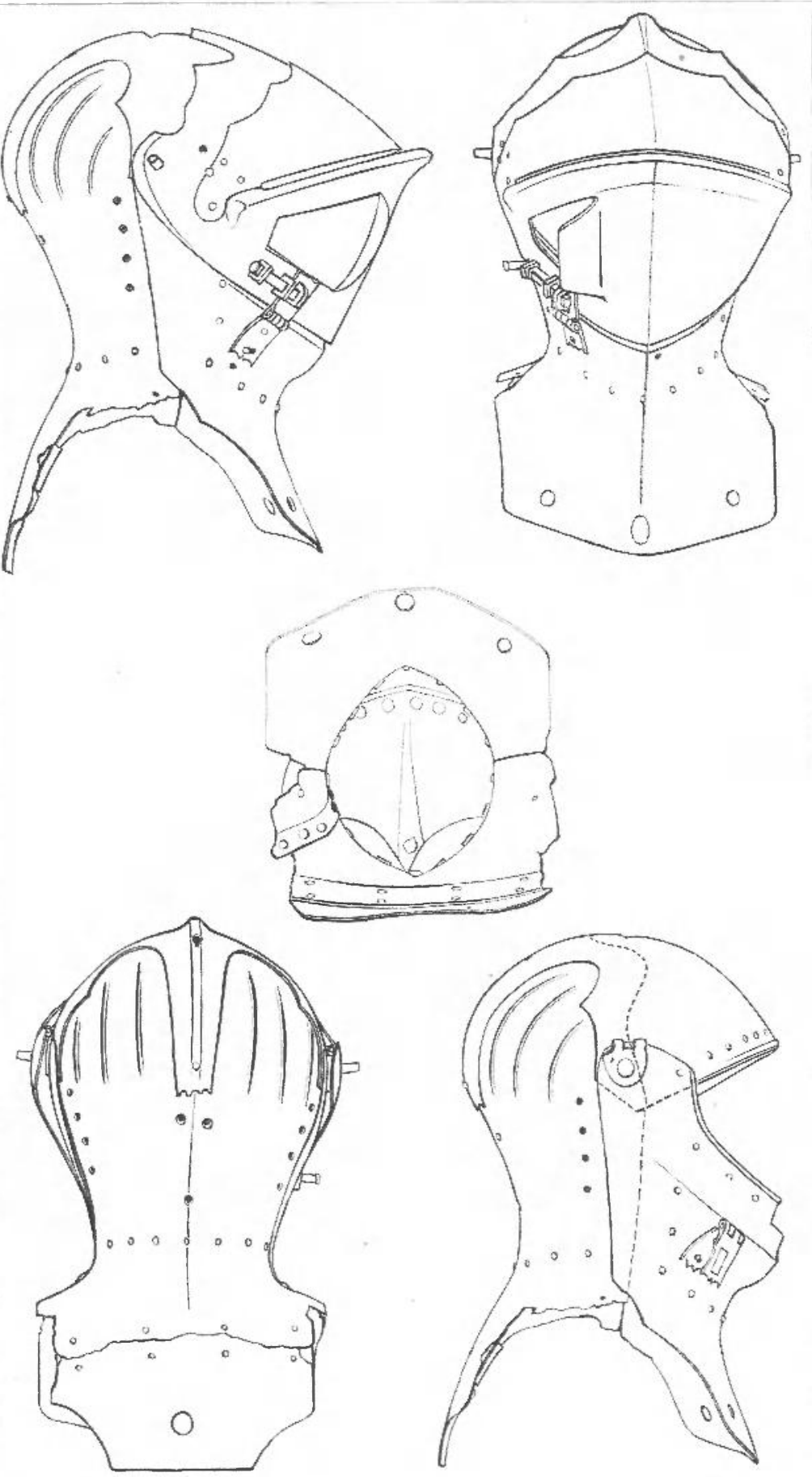

The Hroaduater Helm. 
beyond its contrivance, in the form of a narrow strip to the back of the helm, where it ends abruptly with some slight ornamental chamfers.

On the extreme top is a hole $\frac{1}{2} \mathrm{in}$. diameter, and about 3ins. farther on towards the back a smaller one, of a key shape. These were, doubtless, for the crest (a griffin's head), which, it is quite possible, may not have existed originally, but may have been afterwards added, when the helm was used for funereal purposes. Certain it is, that when the visor is fully raised it covers both holes.

It should be observed that the crown-piece is only attached to the back-piece by a single rivet, about one inch from the termination of the narrow strip, and at the sides, by the rivetted pivots upon which the beaver and hinges of the visor turn.

3. The beaver has the usual rivets for the attachment of the lining along its upper edge, down the sides, and across the middle of the neck. It overlaps the back piece by about one inch, and on the left shoulder there is a hole which may possibly indicate the means of fastening the pieces together by means of hooks. In the front are three holes, half-inch in diameter, the centre one elongated as if by use. These were of course to receive the staples on the breast plate. Just above the chin is a depression to receive the visor. The piece cut out near the mouth has been an afterthought or a mutilation.

4. The visor has had its prolongation terminated like that of the crown piece, only it has been broken off. This visor is remarkable as possessing besides the usual horizontal slit or occularium for sight, an opening on the dexter side, defended from the opposing lance by the metal being turned forward. The roll of the tourniment in the Herald's College shows apertures exactly similar.

The Broadwater helm affords an actual example of a fashion which subsequently became of frequent occurrence, but in these later cases there is generally a little door perforated with holes or ornament, which shuts up and gives greater security in the time of action. Plate 45 of the Triumph of Maximillian shows these openings as closed with unperforated doors.

Another peculiarity in the present visor is the means by which it is hinged. As a general rule the visor works 


\section{THE TOMB AND HELM OF THOMAS IA WARRE,}

on a pivot attached to the body of the helmet; here on the contrary it works on hinges, one of the ends of which is attached to the visor with two rivets, the other end working on the pivot which connects the beaver to the crown and back.

The apparent reason for this arrangement was to prevent the adverse lance striking the projecting point of the pivot, and thus deranging the visor, but in the present instance there are false pivots inserted on the surface of the visor, in the position where the real pivot would appear had the usual arrangement been followed.

I have examined these false pivots most carefully, and am unable to discover their use. They are not threaded for screws, and there are no signs of their having ever been rivetted down. The top of the dexter one, which is five-eighths of an inch in projection, has been split down by two cross cuts to the depth of three-eighths. The sinister, which only projects three-eighths, has no signs of having been split.

The only other remarks about the visor are, that there is a reinforcing piece attached by rivets, and that there are no signs of lining,

Such are the particulars of this very curious helm, which may possibly have been made as an experiment, just as that which was worn by Henry VIII, when he had so narrow an escape in the tournament described by Hall.

It is to be hoped that the helm, being now placed out of reach, will be preserved for many generations. It is difficult to imagine what must have been lost by the practice of despoiling churches for the collections of Antiquaries. Perhaps if a correct list were made and published by the Archæological Institute, or some other body, of the helmets still existing in churches, a little might be done to prevent their removal, as no one would care to show an acquisition derived from a church.

Referring to the aperture for air on the dexter side of the beaver, which we have seen beginning as a mere hole with the iron turned up in front, in the Broadwater helm, and in the Toumeyment Roll of Henry VIII; then becoming a hinged door, in the Triumph of Maximillian; and finally having this door pierced in an ornamental pattern, as shown in Plates $\mathrm{Ix}$ and $\mathrm{x}$ of Skelton's Meyrick Collection, it may, perhaps, be as well to correct the common mistake, that a similar aperture was the cause of the death of Henry II. of France. 
In the description of Plate $\mathrm{x}$ in the above work, we are told, concerning the lielmet here represented: "This, as in the last instance, was protected by a mentonniere, with a small door in it, perforated to give a little air, and made to open when more was required; this, when shut, was kept in its place by means of a catch. It was the sudden opening of it that, accorling to Iavilla, occasioned the death of Henry II. of France, when jousting in 1559 with Gabriel Count de Montgomeri, captain of his guard. The lances had short iron heals, and that of lis antagonist struck him in the right eye and piercerl his brain. His was, probably, like what is represented in Plate xxxi, fig. $i$, as the perforations in this ventilator are an improvement."

The next thing is to turn the original book entitled-Dell 'istoria delle guerre civili di Francia di Arrigo Caterino ; Davilla, Milan, 1807. In lib. 1 , p. 39 , we fincl the following account of the transaction: "On the last day of Jume, in the public celebration of a superb toumeyment, whilst jousting with iron pointed lances with Gabriel, Count of Montgomeri, captain of his guard, the visor of his helmet having got open by chance (apertas'egli per acciclente), he was gravely wounded by the truncheon of the lance of his antversary in the right eye, and forthwith carried for dead into the palace of the Toumelles."

It will be observed that nothing is said of the rontilator.

The next authority is Vincent Carlois, anthor of the Menois sur le Marechal ale Vieituille, whom he served for thirty-six years as secretary. The memoirs extend from 1528 to 1573 .

"For both (the King and Montgomery) very valorously ruming the course, and with great dexterity and aldress having broken their lances, this unskilful (mallhabile) Lorges (Montgomery) did not throw away, as is the ordinary custom, the truncheon which remained in lis hand after the lance lad been broken but carried it lowered, and in finishing the course it met with the head of the king, whom he struck on the visor, which the blow caused to fly up and put out his eye. His Majesty was obliged to hold on by the neck of his horse, which, having the reins loose, finished lis course."

Le Ticomte Jean de Saulx in his Momoirs sur Gaspard de Saul.c Tratennes, his father, which memoirs extend from 1515 to 1573 , gives the following amount of the transaction. "These combats (the jousts) lasted two days. On the third, Montgomery, after making several refusals of jousting against the king, breaks his lance against the breastplate, one of the splinters raises the visor, another pierces the eye of lis majesty, goes out by the ear, and frightens M. le Connestable who sees his favor gone. Some persons accuse the armourers, others the impatience of the king who would not wait to have the look of the visor fastened."

Hall relates how Henry VIII. very nearly met with the same sort of accident as that which befel Henry II. of France.

In this case the king land neglected to put down his visor, and the Duke of Suffolk's spear hit him on the foreheal of the crown piece, pushing the visor further back, and filling the King's helmet with splinters. Hanl the Duke's spear been a little mone lowered than it happener to be, of course Henry would have been killed. As it happened, his escape was a pure matter of chance, as the Duke confessed he could not see as his helmet was so close. 